до саморозвитку. Тобто, курсант разом 3 викладачем оцінюють не відповідність отриманого показника до контрольного нормативу, a рівень зростання (покращення) конкретного показника, шляхом порівняння показників - фонового 3 поточним. Відсоток зростання показника буде свідчити про певний рівень розвитку в курсанта окресленої компетентності: початковий, достатній, зразковий.

Отже, компетентнісно орієнтована Ф і ПФП потребує зламу певних стереотипів як у плануванні занять, так і в оцінюванні індивідуальних досягнень курсантів-пілотів у розвитку їх психофізіологічної надійності. Все це потребує відповідної практики і конструктивних теоретичних напрацювань.

Література:

1. Макаров Р.Н. Фурдуй Я.О. Научные основы физической подготовки летного состава. М, 2007. 920 с.

2. Пивень М.И., Ищенко А.В. Специальная физическая и психофизиологическая подготовка курсантов-пилотов. Кировоград: КДПУ, 2016. 248 с.

DOI https://doi.org/10.30525/978-9934-26-173-2-47

\title{
THE USE OF GRAPHIC LITERACY IN THE CONSTRUCTION OF IMAGES IN THE STUDY OF PERSPECTIVE IN EDUCATIONAL INSTITUTIONS OF PROFESSIONAL, TECHNICAL, ART AND PEDAGOGICAL ORIENTATION
}

\author{
Poltorak A. V. \\ Senior lecturer of the department of technological \\ and professional education \\ State Institution "South Ukrainian National Pedagogical University \\ named after K. D. Ushinsky" \\ Odessa, Ukraine
}

In our time of rapid scientific and technological progress, graphic literacy is a necessary component of everyone's education. Drawings accompany us all our lives, helping us to understand the various issues of science, technology, art and education.

The scientist O. Zaika gives an interpretation of the concept of "Graphic Literacy" as the ability to read various graphic images (drawings, diagrams, 174 
charts, technical drawings, etc.) and the ability to build (perform) them with different drawing tools, as well as by hand, by eye [2].

In many fields of science and technology, education, design in the fine arts are used a variety of images - drawings, diagrams, photographs, and more. Any image is a combination in the plane of dots, lines, tonal and color spots, grouped by a certain system. The study of methods of construction on the plane of graphic images of spatial figures is engaged in perspective - the science of ways to represent spatial forms on the plane.

Perspective is the science of constructing images of spatial forms on surfaces. The study of perspective as a subject in the specialties 014 Secondary education (Labor training and technology) and 015 Professional education (Design) is necessary not so much to be able to build with a line of perspective images, but to draw correctly from nature and by design.

That is why the subject of perspective is an important component of modern educational programs for higher education institutions. It should be noted that for many areas of professional activity the study of promising constructions has a special, priority importance.

Perspective is an integral part of any art or design activity. Therefore, a special place is given to the study of this subject in educational institutions of professional, technical, art and pedagogical orientation. Mastering the skills of promising constructions is necessary not only to be able to build with the help of drawing tools, but also to draw correctly from nature and by design. Based on theoretical knowledge of the rules of construction of promising images, the designer and technologist has the opportunity to competently build a composition, while creatively processing the image according to his plan.

One of the areas of work of vocational and pedagogical educational institutions is the training of specialists in design, technology, science of rational and aesthetic design of human living space. In addition, interior design is part of the curriculum of general secondary education, which necessitates the mastery of relevant skills of future teachers. This field, like no other, requires from the specialist the ability to use the means of constructing perspective. A well-chosen point of view allows you to best reveal the specifics of an interior, show its benefits and features. At the same time, in the process of building interior images, it is not necessary to fully follow the rules of perspective construction, as it introduces some distortions, but it is necessary to know the basic laws of perspective and, based on them, creatively rework the image [1].

Creating promising constructions requires a higher level of development of spatial thinking, the ability to create clear images of objects in the imagination. The formation and development of these qualities occurs in the process of mastering the relevant knowledge and skills, provided the proper 
organization of the educational process. The effectiveness of the educational process is possible only if the correct combination of lecture material with independent work of students of higher education. After all, the development of skills of promising constructions requires systematic independent practical work on the material: solving problems, performing individual tasks, creative work. This is devoted to a third of the study time provided by the curriculum of the specialty for the course.

\title{
References:
}

1. Bovkun S. A. Linear perspective : textbook. Zaporozhye: ZNTU, 2017. 116 p. URL: http://eir.zntu.edu.ua/bitstream/123456789/2527/1/ Bovkun_Tutorial_on_discipline.pdf (date of access: 11.11.2021).

2. Zaika O. Development of graphic literacy in future teachers of mathematics. Collection of scientific works of uman state pedagogical university. Uman, 2018. No. 2. P. 89-98. URL: https://doi.org/10.31499/ 2307-4906.2.2018.149223 (date of access: 24.11.2021).

DOI https://doi.org/10.30525/978-9934-26-173-2-48

\section{ОСОБЛИВОСТІ РОЗВИТКУ ВОКАЛЬНОГО ДИХАННЯ У ПРОЦЕСІ ПІДГОТОВКИ МАЙБУТНЬОГО ВИКЛАДАЧА МИСТЕЦЬКОЇ ШКОЛИ}

\author{
Процишина О. Ю. \\ аспірантка кафедри музикознавства та музичної освіти \\ Київський університет імені Бориса Грінченка \\ м. Київ, Україна
}

Сучасний викладач мистецької школи для вирішення актуальних питань вокальної педагогіки повинен володіти глибокими знаннями 3 теорії та методики навчання співу, знати особливості будови та функціонування голосового апарату, у тому числі й органів дихання. Щоб досягнути педагогічної майстерності майбутньому викладачу мистецької школи у процесі фахової підготовки у ЗВО слід оволодіти традиційними методиками постановки голосу та сучасними методами розвитку творчих, вокальних навичок учнів. Серед таких методів важливе місце посідають методи розвитку та вдосконалення вокального (співацького) дихання. 